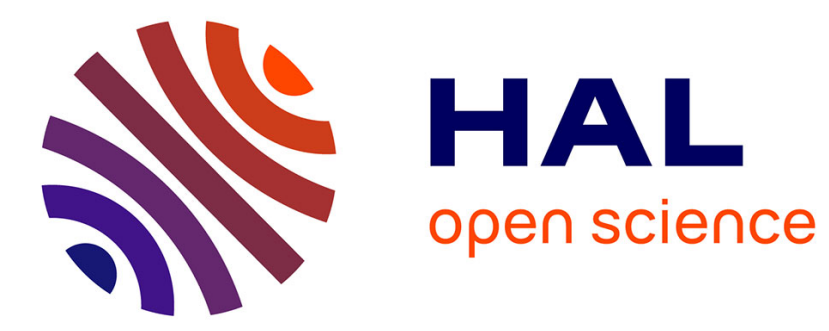

\title{
Internalization and Processing of Human Angiogenin by Cultured Aortic Smooth Muscle Cells
}

\author{
Elissavet Hatzi, Yann Bassaglia, Josette Badet
}

\section{To cite this version:}

Elissavet Hatzi, Yann Bassaglia, Josette Badet. Internalization and Processing of Human Angiogenin by Cultured Aortic Smooth Muscle Cells. Biochemical and Biophysical Research Communications, 2000, 267 (3), pp.719-725. 10.1006/bbrc.1999.2015 . hal-01883788

\section{HAL Id: hal-01883788 \\ https://hal.science/hal-01883788}

Submitted on 28 Sep 2018

HAL is a multi-disciplinary open access archive for the deposit and dissemination of scientific research documents, whether they are published or not. The documents may come from teaching and research institutions in France or abroad, or from public or private research centers.
L'archive ouverte pluridisciplinaire HAL, est destinée au dépôt et à la diffusion de documents scientifiques de niveau recherche, publiés ou non, émanant des établissements d'enseignement et de recherche français ou étrangers, des laboratoires publics ou privés. 
Biochemical and Biophysical Research Communications 267, 719 -725 (2000) https://doi.org/10.1006/bbrc.1999.2015

Manuscript submitted to Biochemical Biophysical Research Communications

\section{Internalization and Processing of Human Angiogenin by Cultured Aortic Smooth Muscle Cells}

Elissavet Hatzi ${ }^{1}$, Yann Bassaglia, and Josette Badet ${ }^{2}$

Laboratoire de Recherche sur la Croissance Cellulaire, la Réparation et la Régénération Tissulaires, Centre National de la Recherche Scientifique, UPRESA 7053, Institut National de la Santé et de la Recherche Médicale, Université Paris XII-Val de Marne, 94010 Créteil, France

1 Present address: Laboratory of Biological Chemistry, University of Ioannina, Ioannina, Greece

2 To whom correspondence should be addressed at: INSERM 427, 4 avenue de l'Observatoire, 75270 Paris Cedex 06, France. Tel.: +33 1537396 04. Fax: +33 1440739 92. E-mail: badet@pharmacie.univ-paris5.fr

Running title: Internalization of angiogenin

Abbreviations: dAng, denatured angiogenin (by reduction and alkylation); SMC, aortic smooth muscle cells.

\section{ABSTRACT}

Human angiogenin is a $14-\mathrm{kDa}$ plasma protein with angiogenic and ribonucleolytic activities. Angiogenin binds specifically to aortic smooth muscle cells, activates second messenger pathways, and inhibits their proliferation. Human and bovine aortic smooth muscle cells were used to study the internalization and intracellular fate of human angiogenin at $37^{\circ} \mathrm{C}$. Using a specific antibody against angiogenin, we found that the internalized native protein was localized in the perinuclear region at $30 \mathrm{~min}$ and then dispersed throughout the cytoplasm. In conditions favoring receptor-mediated endocytosis, internalization of iodinated angiogenin showed a first peak at $5 \mathrm{~min}$ and then further increased for up to $24 \mathrm{~h}$. The halflife of the molecule, calculated as $12 \mathrm{~h}$ in chase experiments, could contribute to its intracellular accumulation. In cell extracts, in addition to the $14-\mathrm{kDa}$ protein, a $8.7-\mathrm{kDa}$ fragment was observed at $24 \mathrm{~h}$, and three fragments with molecular mass of 10.5, 8.7, and 6.1 $\mathrm{kDa}$ were detected at $48 \mathrm{~h}$. Our data point to a specific internalization and processing of human angiogenin by aortic smooth muscle cells. 


\section{INTRODUCTION}

Angiogenin is one of the most potent inducers of neovascularization in experimental models in vivo (1). The human $14-\mathrm{kDa}$ protein shares $35 \%$ amino acid sequence identity with human pancreatic ribonuclease, and has conserved essential active-site residues (2). Angiogenin has ribonucleolytic specificity for ribosomal and transfer RNA (3). A functional enzymatic active site and a cell-binding domain are required to induce angiogenesis (4). Angiogenin binds to endothelial cells (5-7) and vascular smooth muscle cells (8), and activates second messenger pathways $(9,10)$. Furthermore, angiogenin binds tightly to ribonuclease inhibitor, an intracellular protein (11) that abolishes both the enzymatic and angiogenic activities of angiogenin (12).

The specific interactions of angiogenin with vascular smooth muscle cells, together with its ribonucleolytic activity and the intracellular location of the ribonuclease inhibitor, led us to study the internalization and intracellular fate of angiogenin in aortic smooth muscle cells (SMC). We used radiolabeled angiogenin, native angiogenin, and a specific polyclonal antibody. The specificity of the processes studied was assessed by using denatured angiogenin (dAng), which has been shown to exhibit neither ribonucleolytic nor angiogenic activity.

\section{MATERIALS AND METHODS}

Materials. Human recombinant angiogenin with the N-terminal pyroglutamyl residue (wild-type angiogenin) produced either in eucaryotic cells (13) or in Escherichia coli (14) was a gift from R. Shapiro (Boston, MA). It was also prepared according to Shapiro and Vallee (15).

Bovine serum albumin (BSA), fatty-acid-free BSA, insulin, transferrin, ovalbumin, trypsin inhibitor and yeast tRNA (type $\mathrm{X}$ ) were from Sigma Chemical Co. ( $\mathrm{S}^{\mathrm{t}}$ Louis, MO). Culture media, trypsin and gentamycin were from Gibco Laboratories (Grand Island, NY) and fetal bovine serum (FBS) was from Boehringer Mannhein (Germany) and Eurobio (Toulouse, France). Sera were tested for the absence of mycoplasma and were heat-inactivated before use. Angiogenin was 125 I-labeled by the chloramine-T method (16) using $\mathrm{Na}^{125}$ I (ICN Biomedicals Inc., Costa Mesa, CA), and then purified by heparin-Sepharose affinity chromatography (Pharmacia, Uppsala, Sweden) as described elsewhere (8). Specific activity was 2.3-4.6 $\times 10^{5} \mathrm{cpm} / \mathrm{ng}(1.2-3.7 \mathrm{Ci} / \mu \mathrm{mol})$ corresponding to about 1 to 2 atoms of iodine per molecule. Chemicals for SDS-polyacrylamide gel electrophoresis and molecular mass markers were from BioRad (Hercules, CA), and acrylamide was from Serva (Heidelberg, Germany). All chemicals were of analytical grade.

A rabbit polyclonal antibody was prepared against angiogenin. It was purified by chromatography on a G-protein-Sepharose column and then by affinity chromatography on angiogenin immobilized in a CH-Sepharose 4B gel (Pharmacia). The specificity of the anti- 
angiogenin antibody was checked by ELISA, western immunoblotting and immunodiffusion. Goat serum and goat anti-rabbit IgG were from Sigma.

Cells and media. Primary bovine SMC were a gift from P. D'Amore (Boston, MA) and were grown in Dulbecco's modified Eagle's medium (DMEM), 4.5 g/l glucose, 2.2 g/l sodium bicarbonate, 10\% FBS for fewer than ten subcultures. Human SMC immortalized by the E6 and E7 open reading frames of human papillomavirus type 16 (AALTR 16-2 cells), a gift from J. K. McDougall (Seattle, WA), were propagated essentially as reported elsewhere (17), without antibiotics. AALTR 16-2 cells were used between 20 and 26 subcultures. Bovine SMC were cultured in serum-free medium in the conditions described in (18). Cells were grown at $37^{\circ} \mathrm{C}$ in a humidified atmosphere of $5 \% \mathrm{CO}_{2}, 95 \%$ air. The number of cells per culture was determined by counting trypsinized cells with a cell counter (Coultronics, France).

Immunofluorescence staining of cell monolayers. Bovine SMC (15 000-20 000 cells $/ \mathrm{cm}^{2}$ ) cultured for two days in DMEM/10\% FBS were washed twice with phosphatebuffered saline (PBS: $137 \mathrm{mM} \mathrm{NaCl}, 3 \mathrm{mM} \mathrm{KCl}, 6.5 \mathrm{mM} \mathrm{Na}_{2} \mathrm{HPO}_{4}, 1.46 \mathrm{mM} \mathrm{KH}_{2} \mathrm{PO}_{4}, \mathrm{pH}$ 7.4) and then incubated in DMEM/1 mg/ml BSA with or without $100 \mathrm{ng} / \mathrm{ml}$ angiogenin for 3 $\mathrm{h}$ at $37^{\circ} \mathrm{C}$ in humidified air containing $5 \% \mathrm{CO}_{2}$. In parallel experiments, cells were incubated with angiogenin (100 ng/ml, $7 \mathrm{nM}$ ) in binding buffer (20 mM Mops, $130 \mathrm{mM} \mathrm{NaCl}, 1 \mathrm{mM}$ $\mathrm{MgCl}_{2}, 1 \mathrm{mM} \mathrm{CaCl}, 3 \mathrm{mM} \mathrm{KCl}, 1 \mathrm{mg} / \mathrm{ml} \mathrm{BSA}, \mathrm{pH}$ 7.2) for $3 \mathrm{~h}$ at $4^{\circ} \mathrm{C}$. After washing twice with PBS for $5 \mathrm{~min}$, the cells were fixed with $4 \%$ paraformaldehyde in PBS at room temperature for $20 \mathrm{~min}$. After washing once with PBS, the remaining free aldehyde groups were blocked by adding $50 \mathrm{mM} \mathrm{NH} 4 \mathrm{Cl}$ for $10 \mathrm{~min}$. The cells were then washed twice with PBS and permeabilized by adding $0.5 \%$ Triton X-100 in PBS for 5 min. Following three rapid washes with PBS, saturation was performed with PBS, $7 \%$ goat serum, $0.5 \%$ ovalbumin (blocking buffer) for $30 \mathrm{~min}$ at room temperature. Cells were then exposed to $6 \mu \mathrm{g} / \mathrm{ml}$ angiogenin-specific IgG in blocking buffer overnight at $4^{\circ} \mathrm{C}$. After washing twice with PBS for $5 \mathrm{~min}$, the cells were incubated with blocking buffer for $30 \mathrm{~min}$ and the bound antibody was revealed by $2 \mathrm{~h}$ of incubation at room temperature with TRITC-labeled goat anti-rabbit IgG diluted 1:200 in blocking buffer. Finally, the cells were washed twice with PBS and once with distilled water, then mounted in Mowiol (Calbiochem). In control experiments, the primary antibody was either omitted from the incubation medium or replaced by the IgG fraction not retained by the angiogenin-affinity chromatography column. Photographs were taken with an Olympus phase-contrast microscope with fluorescence attachment (BH2RFCA).

Reductive alkylation of angiogenin. Reductive alkylation of native and iodinated angiogenin was performed according to Anfinsen and Haber (19). Two micrograms (52 nM) of angiogenin diluted in $20 \mathrm{mM}$ Mops, $130 \mathrm{mM} \mathrm{NaCl}, 0.2 \mathrm{mg} / \mathrm{ml}$ BSA pH 7.2 was stirred in 8 
M urea, $0.28 \mathrm{M} \mathrm{B-mercaptoethanol,} \mathrm{pH} 8.5$ in a total volume of $2.8 \mathrm{ml}$, for $4 \mathrm{~h}$ at room temperature under nitrogen. The reaction mixture was desalted by filtration on a PD10 Sephadex G25-M column (Pharmacia) equilibrated in $0.1 \mathrm{M}$ acetic acid, and $\mathrm{pH}$ was adjusted to 7.8 by adding 0.6 vol. of $1 \mathrm{M}$ Hepes. Alkylation was then performed in the presence of 25 $\mathrm{mM}$ iodoacetamide for $45 \mathrm{~min}$ at $27^{\circ} \mathrm{C}$ in the dark. After desalting the sample by gel filtration on $\mathrm{G} 25$ in $20 \mathrm{mM}$ Mops, $130 \mathrm{mM} \mathrm{NaCl}, 0.2 \mathrm{mg} / \mathrm{ml} \mathrm{BSA} \mathrm{pH} \mathrm{7.2,} \mathrm{the} \mathrm{denatured} \mathrm{angiogenin}$ (dAng) was concentrated by ultrafiltration through Centricon centrifugal concentrators (10 $000 \mathrm{MW}$ cut-off, Amicon, Beverly, MA) at $5000 \mathrm{x}$ g for $1 \mathrm{~h}$ at $4^{\circ} \mathrm{C}$.

Ribonucleolytic assay. The ribonucleolytic activity of native and alkylated angiogenin was assessed in an agarose gel-based assay (20). The reaction mixture, containing $8 \mathrm{mM}$ Tris $\mathrm{pH} 7.5,12 \mathrm{mM} \mathrm{NaCl}, 1 \mu \mathrm{g}$ of yeast tRNA and $10,25,50$ or $100 \mathrm{ng}$ of angiogenin in a volume of $10 \mu \mathrm{l}$, was incubated for 1 or $2 \mathrm{~h}$ at $37^{\circ} \mathrm{C}$. The reaction was stopped by chilling on ice. Enzymatic degradation was analyzed immediately, by electrophoresis of the samples in $1.5 \%$ agarose gel containing $0.5 \mu \mathrm{g} / \mathrm{ml}$ ethidium bromide.

Cellular uptake of 125I-angiogenin. Cells were seeded at a density of 15 000-20 $000 / \mathrm{cm}^{2}$ in 4 - or 6-well plates (Falcon Becton Dickinson, $\mathrm{NJ}$ ) and cultured for 2 days before experiments. Cells were washed three times with PBS at $37^{\circ} \mathrm{C}$ and incubated with native or denatured $125 \mathrm{I}$-angiogenin $(0.2 \mathrm{nM})$, for the times indicated at $37^{\circ} \mathrm{C}$ in humidified air containing 5\% $\mathrm{CO}_{2}$. Alternatively, cultures were pre-incubated in DMEM/1 mg/ml BSA for 3 $\mathrm{h}$ at $37^{\circ} \mathrm{C}$ before adding angiogenin, to dissociate any secreted angiogenin or interacting molecules from serum bound to the cell surface. The following buffers were used as indicated: DMEM/10\% FBS, DMEM/1 mg/ml BSA, DMEM/1 mg/ml fatty-acid-free BSA/10 $\mu \mathrm{g} / \mathrm{ml}$ transferrin $/ 30 \mu \mathrm{g} / \mathrm{ml}$ insulin $/ 50 \mu \mathrm{g} / \mathrm{ml}$ gentamycin, binding buffer. At the times indicated, cells were cooled to $4^{\circ} \mathrm{C}$ and all subsequent operations were done at this temperature. After washing once with cold PBS, cell monolayers were incubated for 2 min in $1 \mathrm{M} \mathrm{NaCl}, 0.2 \mathrm{M} \mathrm{CH}_{3} \mathrm{COOH} \mathrm{pH} 2.5$ (21) to release surface-bound angiogenin. They were then washed once with PBS, dissociated by trypsin treatment and collected by centrifugation at $450 \mathrm{x} \mathrm{g}$ for $5 \mathrm{~min}$ at $4^{\circ} \mathrm{C}$ in the presence of $1 \mathrm{mg} / \mathrm{ml}$ trypsin inhibitor per $\mathrm{mg}$ trypsin. Alternatively, to release at once bound $125 \mathrm{I}$-angiogenin, the cell monolayer was washed four times with cold PBS and then treated with trypsin, without the acid treatment. The two protocols gave similar results. The pellets were solubilized in $50 \mu 1$ of $2 \mathrm{x}$ electrophoresis sample buffer (1x: $50 \mathrm{mM}$ Tris- $\mathrm{HCl}, 5 \%$ glycerol, 1\% SDS, $0.14 \mathrm{M} \beta$-mercaptoethanol, $0.001 \%$ bromophenol blue, $\mathrm{pH}$ 6.8). Radioactivity was counted using a LKB model 1275 Minigamma counter at $80 \%$ efficiency. In control experiments, cells were cooled to $4^{\circ} \mathrm{C}$, washed four times with cold PBS and then incubated with 125I-angiogenin for $10 \mathrm{~min}$. They were then treated as above. 
Fate of internalized 125I-angiogenin. To study possible degradation of angiogenin, cell pellets were analyzed by SDS-polyacrylamide gel electrophoresis on a $3 \%$ polyacrylamide stacking gel and a $15 \%$ polyacrylamide resolving gel. To visualize $125 \mathrm{I}$-angiogenin and its degradation products, the dried gels were exposed to X-OMat AR autoradiography films (Kodak) at $-80^{\circ} \mathrm{C}$ using intensifying screens.

Chase. The half-life of angiogenin was determined in 2-day cultured bovine SMC and human AALTR-16 cells plated at $15000-20000$ cells $/ \mathrm{cm}^{2}$. Cells were incubated in the presence of $0.2 \mathrm{nM} 125 \mathrm{I}$-angiogenin for $3 \mathrm{~h}$ in either DMEM/1 mg/ml BSA $/ 30 \mu \mathrm{g} / \mathrm{ml}$ insulin $/ 10 \mu \mathrm{g} / \mathrm{ml}$ transferrin or DMEM $/ 10 \% \mathrm{FBS}$, at $37^{\circ} \mathrm{C}$ in humidified air containing $5 \%$ $\mathrm{CO}_{2}$, then washed three times with prewarmed PBS at $37^{\circ} \mathrm{C}$ and finally incubated with 0.2 $\mathrm{nM}$ unlabeled angiogenin and $0.2 \mathrm{nM} 125 \mathrm{I}$-angiogenin, respectively, for 3, 21, 45 and $69 \mathrm{~h}$ in culture medium at $37^{\circ} \mathrm{C}$. At the indicated times, cells were placed at $4{ }^{\circ} \mathrm{C}$ and treated as described above.

\section{RESULTS}

Immunofluorescence detection of internalized angiogenin. Angiogenin uptake by bovine SMC was visualized after immunocytochemical staining with a specific polyclonal antibody against human angiogenin. At $30 \mathrm{~min}$ and $1 \mathrm{~h}$, angiogenin was located in the perinuclear area (Fig. 1B, 1D). After 3 h, bright staining was observed only in the cytoplasm (Fig. 1F). Not all the cells were labeled (Fig. 1D). No labeling was detected using either the IgG fraction not retained by immobilized angiogenin (non specific IgG; not shown) or the 2nd labeled antibody alone (Fig. 1H). Control cells (not exposed to angiogenin) were also negative, as the anti-human angiogenin $\mathrm{IgG}$ did not react with bovine angiogenin (not shown).

Time-course of angiogenin binding and internalization at $37^{\circ} \mathrm{C}$. To examine receptormediated endocytosis, angiogenin internalization was studied in conditions that favored highaffinity binding, as previously determined (8). Sparse cells were incubated in binding buffer with $0.2 \mathrm{nM}{ }^{125} \mathrm{I}$-angiogenin at $37^{\circ} \mathrm{C}$ for the times indicated. Two waves of internalization were observed (Fig. 2). Angiogenin was rapidly internalized with a maximum at 5 min followed by a second increase after $10 \mathrm{~min}$. However, surface-bound angiogenin reached its maximum within $15 \mathrm{~min}$ and then remained constant (Fig. 2, inset). To study the possible influence of serum components such as endogenous angiogenin, bovine SMC were cultured for at least three passages in serum-free medium; similar results were obtained (not shown).

Specificity of internalization. Denatured angiogenin was used to control the specificity of angiogenin internalization, as the high isoelectric point of angiogenin ( $\mathrm{pI}>9.5$ ) could result in extensive binding to negatively charged molecules. Reduced and alkylated angiogenin has neither ribonucleolytic nor angiogenic activity (22). Denatured angiogenin did not hydrolyze yeast tRNA (Fig. 3A). Saturation experiments were performed with the labeled alkylated molecule at $4{ }^{\circ} \mathrm{C}$ and 2-day cultured bovine SMC as described elsewhere (8). Analysis of the 
binding data using the LIGAND program (23) suggested a total or partial loss of recognition of high-affinity binding sites. Furthermore, competition experiments of ${ }^{125}$ I-dAng binding with increasing concentrations of native angiogenin (as well as cross-linking experiments) showed that angiogenin did not affect ${ }^{125}$ I-dAng binding to bovine SMC (not shown and Fig. $3 \mathrm{~B})$. It is worth noting that the acid wash, known to disrupt ligand-receptor interactions $(8,21)$, had little effect on the removal of dAng from the cell surface compared to native angiogenin. Most cell-bound dAng was sensitive to trypsin treatment.

To study angiogenin internalization, $0.2 \mathrm{nM}{ }^{12} 5_{\text {I-angiogenin (native or denatured) was }}$ added to 2-day cultured bovine SMC for $3 \mathrm{~h}$ at $37^{\circ} \mathrm{C}$ in the presence or absence of serum. The results showed that the two molecules were internalized by SMC but the amounts of internalized dAng were always lower, despite its higher total binding to the cell surface. Maximal internalization of the two molecules was obtained in serum-free medium (Fig. 3C).

Internalization of angiogenin and dAng did not occur via the same pathway, as dAng failed to chase internalized ${ }^{125}$ I-angiogenin during $48 \mathrm{~h}$ of incubation, whereas angiogenin chased $85 \%$ of 125 I-angiogenin (not shown).

Long-term internalization. The kinetics of angiogenin and dAng internalization was studied at $37^{\circ} \mathrm{C}$ to investigate the intracellular fate of the molecules. Two-day cultured bovine SMC were placed in serum-free medium and incubated with $0.2 \mathrm{nM}{ }^{125}$ I-angiogenin for 15 min and $1,3,6$ and $24 \mathrm{~h}$ at $37^{\circ} \mathrm{C}$. The amount of internalized angiogenin increased with the incubation time (Fig. 4A), and intracellular accumulation of angiogenin was observed.

To visualize the intracellular fate of angiogenin, the cell pellets were analyzed by SDSPAGE and autoradiography. Figure 4B shows the partial degradation of the two angiogenin forms. A single degradation product of $8.7 \mathrm{kDa}$ was detected at $6 \mathrm{~h}$ with native ${ }^{125} \mathrm{I}$ angiogenin. In contrast, ${ }^{125} \mathrm{I}$-dAng was processed into fragments detected at $1 \mathrm{~h}$ of incubation, and its degradation was more extensive, as two bands with molecular mass of 10.2 and $8.7 \mathrm{kDa}$ were visualized at $24 \mathrm{~h}$.

Chase studies. Human immortalized SMC (AALTR 16-2) were used to study species

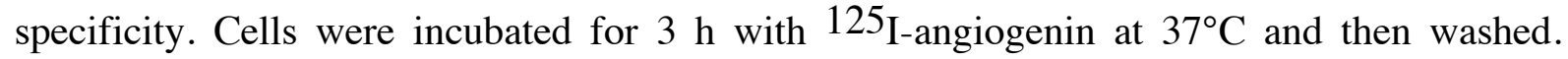
Internalized ${ }^{125} \mathrm{I}$-angiogenin was chased by the same amounts of native angiogenin for 3,21 and $45 \mathrm{~h}$. The amount of internalized radioactivity fell with time and reached a plateau at 24 h. (Fig. 5A). The half-life of the molecule was calculated to be $12 \mathrm{~h}$. The radioactivity released in the incubation medium supported the chase of the internalized molecule. These results were confirmed by SDS-PAGE of the cells. After a 45-h chase with unlabeled angiogenin, no ${ }^{125}$ I-angiogenin was detected inside the cells. However, chase experiments with ${ }^{125}$ I-angiogenin indicated that angiogenin continued to enter the cells, as intracellular accumulation of radioactivity was observed, and three degradation fragments $(10.5,8.7$, and $6.1 \mathrm{kDa}$ ) were visualized (Fig. 5B). This processing did not occur through a lysosomal pathway, as methylamine $(30 \mathrm{mM})$ and ammonium chloride $(20 \mathrm{mM})$, both of which 
indirectly inactivate lysosomal hydrolases, had no effect on angiogenin degradation (data not shown).

\section{DISCUSSION}

Sparse SMC express two classes of angiogenin binding site. On bovine SMC, highaffinity binding sites with an apparent dissociation constant $\left(K_{\mathrm{d}}\right)$ of $2 \times 10^{-10} \mathrm{M}$ bind $1 \times 10^{4}$ molecules/cell, and low-affinity binding sites $\left(K_{\mathrm{d}}=1 \times 10^{-7} \mathrm{M}\right)$ bind millions of molecules. The number of high-affinity binding sites decreases as cell density increases, and they are no longer detected at confluence (8). They are probably cell-surface receptors, as angiogenin in the concentration range of its high-affinity $K_{\mathrm{d}}$ activates second messenger pathways (10), and inhibits SMC proliferation (8). To learn more of the intracellular function and/or regulation of angiogenin, its binding, internalization and processing by bovine and human SMC were studied at $37^{\circ} \mathrm{C}$.

In conditions targeting high-affinity binding sites, ${ }^{125}$ I-angiogenin binding to the cell surface reached a plateau by $15 \mathrm{~min}$, which reflected a steady state among several concomitant processes, including cell-surface binding, intracellular transit and processing, and discharge of angiogenin and/or its fragments into the extracellular medium. In contrast with the rapid binding, internalization peaked at $5 \mathrm{~min}$, and ${ }^{125}$ I-angiogenin continued to accumulate in the cells after $15 \mathrm{~min}$, for up to $24 \mathrm{~h}$. This intracellular accumulation suggests that the cell surface is replenished with angiogenin receptors either recycled after internalization or supplied by a large intracellular pool. The 12-h half-life of the molecule, calculated from chase experiments, could also contribute to its intracellular accumulation. In these conditions, $5-10 \%$ of ${ }^{125}$ I-angiogenin bound to the cell surface was internalized by SMC (corresponding to 400-1000 molecules/cell). The small number of internalized molecules might reflect an intracellular function.

Surface-binding and internalization of ${ }^{125}$ I-angiogenin by SMC were also examined as a function of the angiogenin concentration from 0.2 to $65 \mathrm{nM}$ (not shown). When the angiogenin concentration was higher than the dissociation constant for high-affinity binding sites, binding of the molecule to the cell surface reached the maximal level more rapidly, and an increase in the amount of internalized ${ }^{125}$ I-angiogenin was observed. This suggests that, in addition to receptor-mediated internalization, angiogenin endocytosis occurs via other routes which could involve low-affinity binding sites.

Immunostaining experiments using an angiogenin concentration in the low-affinity $K_{\mathrm{d}}$ range $(100 \mathrm{ng} / \mathrm{ml})$ showed a perinuclear localization of internalized angiogenin at $30 \mathrm{~min}$ and $1 \mathrm{~h}$. Similar observations have been made with endothelial cells and $1 \mu \mathrm{g} / \mathrm{ml}$ angiogenin, with a nucleolar location (24). However, angiogenin was dispersed in the SMC cytoplasm after $3 \mathrm{~h}$ of internalization. 
Interestingly, internalized angiogenin is resistant to cellular degradation. In addition to the $14-\mathrm{kDa}$ protein, a single $8.7-\mathrm{kDa}$ fragment was observed at $24 \mathrm{~h}$, and three fragments $(10.5,8.7$, and $6.1 \mathrm{kDa})$ were detected at $48 \mathrm{~h}$. Angiogenin processing does not occur in lysosomes, as it was not inhibited by the lysosomotropic bases ammonium chloride and methylamine (not shown) which inhibit degradative agents by raising the lysosomal $\mathrm{pH}(25)$. This supports the specificity of angiogenin internalization, as degradation of RNase A (68\% homologous to angiogenin) occurs exclusively in lysosomes (26-28). The specificity of processing is also suggested by the rapid degradation of denatured angiogenin. Angiogenin is resistant to a wide variety of proteolytic enzymes (29) but is cleaved by human neutrophil elastase (30). Note that angiogenin belongs to the RNase family whose members are resistant to intracellular degradation (31). The small size and the basic isoelectric point could explain the long intracellular life of these molecules (28). Restricted endosomal proteolysis is used both for inactivation (e.g. insulin, glucagon and epidermal growth factor) and activation (e.g. lysosomal hydrolases, toxins and parathyroid hormone) of internalized proteins through a receptor-mediated pathway $(32,33)$. Further studies are needed to determine whether this process is involved in the regulation of angiogenin functions.

As angiogenin is present in plasma (34), the specific binding of human angiogenin to SMC, together with its internalization and metabolism, supports the involvement of angiogenin in vessel wall homeostasis.

\section{ACKNOWLEDGMENTS}

We are grateful to Dr C. Dorey for preparing anti-angiogenin antibodies and to D. Young for editorial assistance. We thank Dr P. D'Amore (Boston, MA) for the gift of bovine aortic SMC, Dr J. K. McDougall (Seattle, WA) for AALTR 16-2 cells, and Dr B. L. Vallee (Boston, MA) for human recombinant angiogenin. We express our gratitude to Dr. D. Barritault, in whose laboratory we developed the angiogenin project. This work was supported by the Association de la Recherche sur le Cancer (grant $n^{\circ} 6831$ ), la Fondation de France, and la Fondation pour la Recherche Médicale. E.H. was supported by fellowships from the Ministère de la Recherche et de la Technologie and from the Association de la Recherche sur le Cancer.

\section{REFERENCES}

1. Fett, J. W., Strydom, D. J., Lobb, R. R., Alderman, E. M., Bethune, J. L., Riordan, J. F., and Vallee, B. L. (1985) Biochemistry 24, 5480-5486

2. Strydom, D. J., Fett, J. W., Lobb, R. R., Alderman, E. M., Bethune, J. L., Riordan, J. F., and Vallee, B. L. (1985) Biochemistry 24, 5486-5494

3. Shapiro, R., Riordan, J. F., and Vallee, B. L. (1986) Biochemistry 25, 3527-3532

4. Hallahan, T. W., Shapiro, R., and Vallee, B. L. (1991) Proc. Natl. Acad. Sci. USA 88, 2222-2226

5. Badet, J., Soncin, F., Guitton, J.-D., Lamare, O., Cartwright, T., and Barritault, D. (1989) Proc. Natl. Acad. Sci. USA 86, 8427-8433

6. Chamoux, M., Dehouck, M. P., Fruchart, J. C., Spik, G., Montreuil, J., and Cecchelli, R. (1991) Biochem. Biophys. Res. Commun. 176, 833-839

7. Hu, G.-F., Riordan, J. F., and Vallee, B. L. (1997) Proc. Natl. Acad. Sci. USA 94, 2204-2209

8. Hatzi, E., and Badet, J. (1999) Eur. J. Biochem. 260, 825-832 
9. $\quad$ Bicknell, R., and Vallee, B. L. (1989) Proc. Natl. Acad.Sci. USA 86, 1573-1577

10. Moore, F., and Riordan, J. F. (1990) Biochemistry 29, 228-233

11. Hofsteenge, J. (1997) in Ribonucleases: structures and functions (D'Alessio, G., and Riordan, J. F., eds), pp. 621-658., Academic Press, New York

12. Shapiro, R., and Vallee, B. L. (1987) Proc. Natl. Acad. Sci. USA 84, 2238-2241

13. Kurachi, K., Rybak, S. M., Fett, J. W., Shapiro, R., Strydom, D. J., Olson, K. A., Riordan, J. F., Davie, E. W., and Vallee, B. L. (1988) Biochemistry 27, 6557-6562

14. Shapiro, R., Harper, J. W., Fow, E. A., Jansen, H. W., Hein, F., and Uhlmann, E. (1988) Anal. Biochem. 175, 450-461

15. Shapiro, R., and Vallee, B. L. (1992) Biochemistry 31, 12477-12485

16. Hunter, W. M., and Greenwood, F. C. (1962) Nature (London) 194, 495-496

17. Perez-Reyes, N., Halbert, C. L., Smith, P. P., Benditt, E. P., and McDougall, J. K. (1992) Proc. Natl. Acad.Sci. USA 89, 1224-1228

18. Moenner, M., Hatzi, E., and Badet, J. (1997) In Vitro Cell. Dev. Biol. 33, 553-561

19. Anfinsen, C. B., and Haber, E. (1961) J. Biol. Chem. 236, 1361-1363

20. Gullberg, U., Widegren, B., Arnason, U., Egesten, A., and Olsson, I. (1986) Biochem. Biophys. Res. Commun. 139, 1239-1242

21. Haigler, H. T., Maxfield, F. R., Willingham, M. C., and Pastan, I. (1980) J. Biol. Chem. 255, 1239-1241

22. Shapiro, R., Weremowicz, S., Riordan, J. F., and Vallee, B. L. (1987) Proc. Natl. Acad. Sci. USA 84, 8783-8787

23. Munson, P. J., and Rodbard, D. (1980) Anal. Biochem. 107, 220-239

24. Moroianu, J., and Riordan, J. F. (1994) Proc. Natl. Acad. Sci. USA 91, 1677-1681

25. Ohkuma, S., and Poole, B. (1978) Proc. Natl. Acad. Sci. USA 75, 3327-3331

26. Cuervo, A. M., and Dice, J. F. (1998) J. Mol. Med. 76, 6-12

27. Dice, J. F., Backer, J. M., Miao, P., and al., e. (1985) Prog. Clin. Biol. Res. 180, 385-394

28. Dice, J. F. (1987) FASEB J. 1, 349-357

29. Harper, J. W., and Vallee, B. L. (1988) J. Prot. Chem. 7, 355-363

30. Hu, G.-F. (1997) J. Protein Chem. 16, 669-679

31. Neff, N. T., Bourret, L., Miao, P., and Dice, J. F. (1981) J. Cell. Biol. 91, 184-194

32. Berg, T., Gjøen, T., and Bakke, O. (1995) Biochem. J. 307, 313-326

33. Authier, F., Posner, B. I., and Bergeron, J. J. M. (1996) FEBS Lett. 389, 55-60

34. Shapiro, R., Strydom, D. J., Olson, K. A., and Vallee, B. L. (1987) Biochemistry 26, 5141-5146 


\section{Figure legends}

FIG. 1. Immunolocalization of internalized angiogenin in bovine SMC. Cells were incubated with $100 \mathrm{ng} / \mathrm{ml}$ angiogenin for $0.5 \mathrm{~h}(\mathrm{~A}, \mathrm{~B}, \mathrm{G}, \mathrm{H}), 1 \mathrm{~h}(\mathrm{C}, \mathrm{D})$ and $3 \mathrm{~h}(\mathrm{E}-\mathrm{F})$ at $37^{\circ} \mathrm{C}$, fixed in $4 \%$ paraformaldehyde and permeabilized, and then incubated with $6 \mu \mathrm{g} / \mathrm{ml}$ antiangiogenin $\mathrm{IgG}$ overnight at $4^{\circ} \mathrm{C}$. Bound antibody was revealed by 2 -h incubation with TRITC-labeled goat anti-rabbit. (G, H) Control experiment without anti-angiogenin IgG. (A, C, E, G) Phase-contrast. Bar: $20 \mu \mathrm{m}$.

FIG. 2. Time-course of ${ }^{125}$ I-angiogenin internalization (Ang) by bovine SMC at $37^{\circ} \mathrm{C}$. Two-day cultured SMC were incubated with $0.2 \mathrm{nM} 125 \mathrm{I}$-angiogenin in binding buffer. At the times indicated the monolayers were washed four times with cold PBS and the cells were collected by trypsin treatment and centrifugation. Surface-bound ${ }^{125}$ I-angiogenin was released into the supernatant (inset), and internalized radioactivity was determined in the pellets. Results are means \pm SD of triplicate determinations. The profiles are representative of three independent experiments.

FIG. 3. Characteristics of denatured angiogenin. (A) Ribonucleolytic activity on yeast tRNA. Various amounts of native and denatured angiogenin (Ang and dAng, respectively) were incubated with $1 \mu \mathrm{g}$ of tRNA in $8 \mathrm{mM}$ Tris, $\mathrm{pH} 7.5,12 \mathrm{mM} \mathrm{NaCl}$ for $1.5 \mathrm{~h}$ at $37^{\circ} \mathrm{C}$. The reaction products were cooled to $4^{\circ} \mathrm{C}$ and analyzed by electrophoresis in a $1.5 \%$ agarose gel. 1: $10 \mathrm{ng}$; 2: $25 \mathrm{ng}$; 3: $50 \mathrm{ng}$; 4: $100 \mathrm{ng}$. Cltr: incubation of $1 \mu \mathrm{g}$ tRNA in the absence of angiogenin. (B) Cross-competition of ${ }^{125}$ I-angiogenin and ${ }^{125}$ I-dAng binding to sparse SMC by a 100-fold excess of angiogenin and dAng, respectively. SMC were incubated for $3 \mathrm{~h}$ at $4{ }^{\circ} \mathrm{C}$ with $0.8 \mathrm{nM}{ }^{125}$ I-angiogenin and ${ }^{125}$ I-dAng in binding buffer $\left(*\right.$ : ${ }^{125}$ I-angiogenin was $0.14 \mathrm{nM})$. Cell-associated radioactivity was counted in triplicate wells. Results are expressed as $\%$ of radioactivity competed in the presence of competitor. (C) Specificity of angiogenin internalization by SMC. Two-day sparse bovine SMC $\left(19000 / \mathrm{cm}^{2}\right)$ were incubated either in DMEM/10\% FCS (serum) or in DMEM/ $1 \mathrm{mg} / \mathrm{ml} \mathrm{BSA} / 10 \mu \mathrm{g} / \mathrm{ml}$ transferrin $/ 30 \mu \mathrm{g} / \mathrm{ml}$ insulin (serum-free) in the presence of ${ }^{125}$ I-angiogenin and ${ }^{125} \mathrm{I}$-dAng $(0.2 \mathrm{nM})$ for $3 \mathrm{~h}$ at $37^{\circ} \mathrm{C}$. They were then placed on ice and washed with cold PBS. An acid wash with $1 \mathrm{M} \mathrm{NaCl}, 0.2$ $\mathrm{M} \mathrm{CH}_{3} \mathrm{COOH}$, pH 2.5 was then performed and the cells were collected by trypsin treatment and centrifugation. Surface-bound radioactivity was the sum of acid-wash and supernatant counts. Internalized radioactivity was determined in the pellets. Results are means \pm SD of triplicate determinations. 
FIG. 4. Time-course of radiolabeled-angiogenin internalization and degradation at $37^{\circ} \mathrm{C}$.

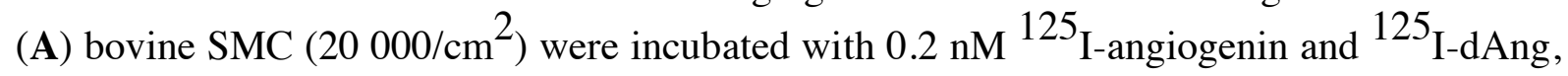
respectively, in DMEM/1 $\mathrm{mg} / \mathrm{ml} \mathrm{BSA} / 10 \mu \mathrm{g} / \mathrm{ml}$ transferrin $/ 30 \mu \mathrm{g} / \mathrm{ml}$ insulin for the times indicated. Then they were cooled to $4^{\circ} \mathrm{C}$, washed and acid-treated for $2 \mathrm{~min}$ to release surface-bound angiogenin. They were then washed again, treated with trypsin and centrifuged. Supernatants were used to measure surface-bound angiogenin. Internalized radioactivity was determined in the pellets. Results are means \pm SD of triplicate determinations. (B) Cells were analyzed by SDS-PAGE and autoradiography. The dried gels were exposed for 4 days. Bands are shown with their approximate molecular mass (kDa). Degradation of internalized ${ }^{125}$ I-angiogenin (a) and ${ }^{125}$ I-dAng (b). Ctlr: In control experiments, radiolabeled angiogenin was added for $10 \mathrm{~min}$ at $4^{\circ} \mathrm{C}$, and the cells were then treated as above.

FIG. 5. Pulse-chase studies of internalized ${ }^{125}$ I-angiogenin in human SMC. (A) AALTR $16-2$ cells $\left(18000 / \mathrm{cm}^{2}\right)$ were pulsed with ${ }^{125}$ I-angiogenin $(0.2 \mathrm{nM})$ for $3 \mathrm{~h}$ and chased with $0.2 \mathrm{nM}$ angiogenin $(\square)$ or ${ }^{125}$ I-angiogenin $(O)$ for 3,21 and $45 \mathrm{~h}$ in DMEM/10\% FCS. Then, cells were placed on ice and treated as indicated in Fig. 4. (B) Cells were analyzed by SDS-PAGE and autoradiography of the gel at $48 \mathrm{~h}$. Ctlr: In control experiments, ${ }^{125}$ I-angiogenin was added for $10 \mathrm{~min}$ at $4^{\circ} \mathrm{C}$, and the cells were then treated as above. a: Chase by ${ }^{125}$ I-angiogenin; b: chase by angiogenin; Ang: ${ }^{125}$ I-Ang (4000 cpm). 

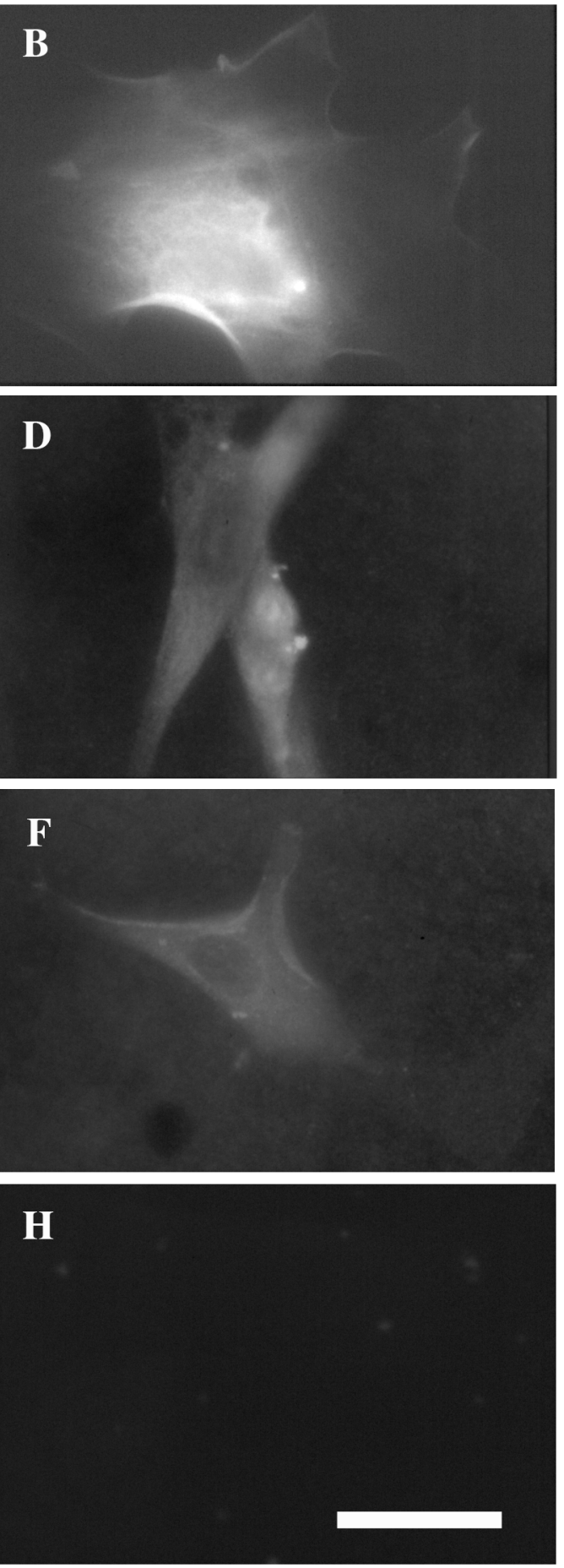

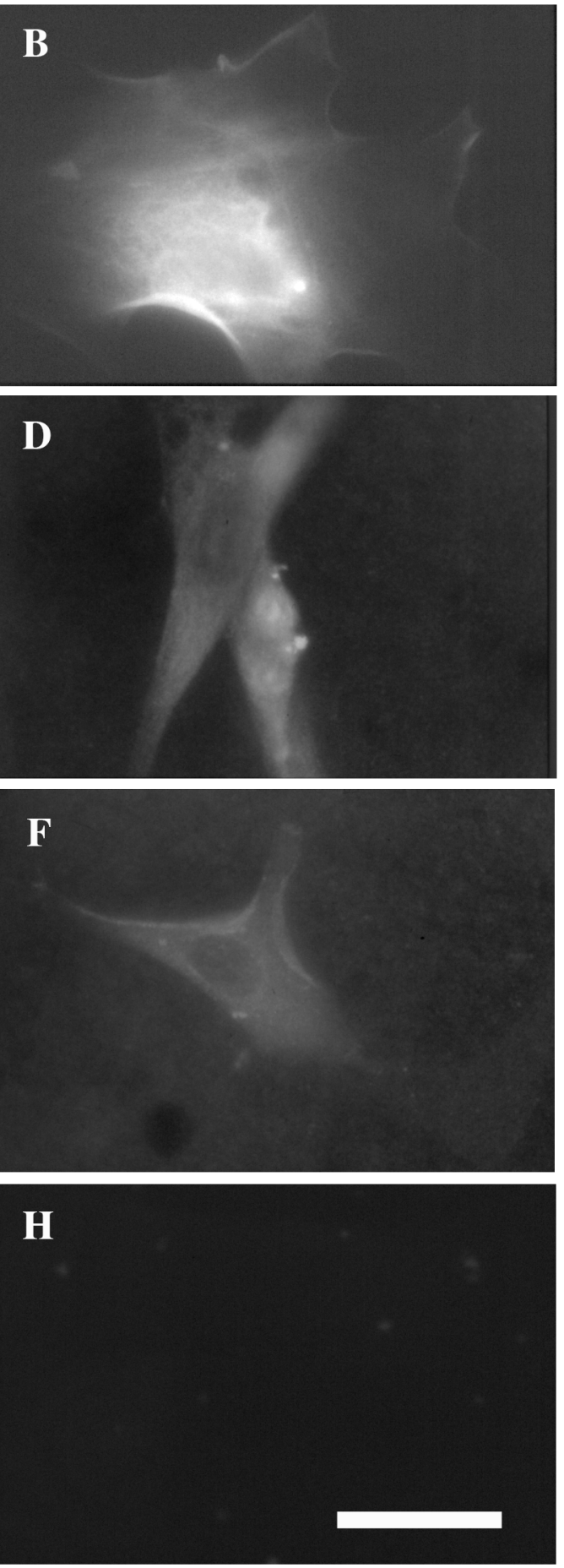
Figure 2

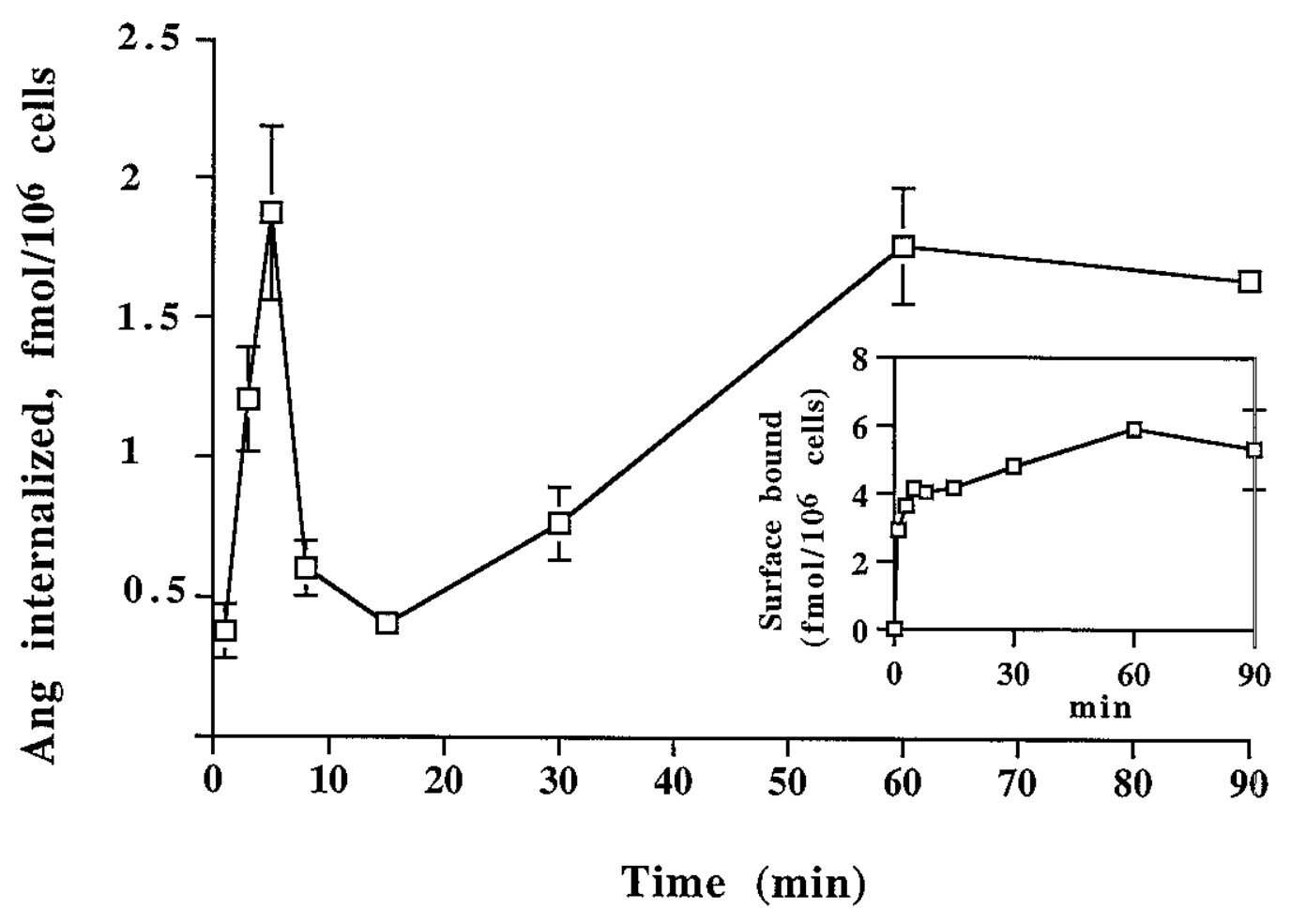


Figure 3

A

Ribonucleolytic activity of angiogenin

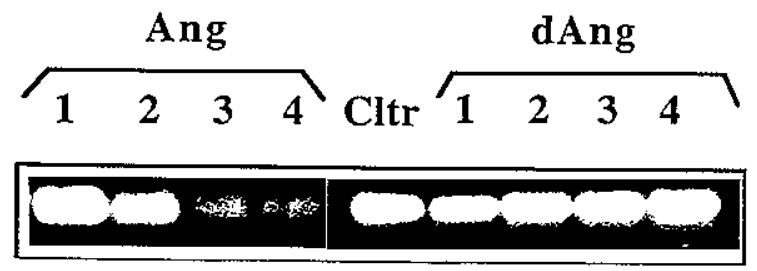

B

Competition of binding to SMC (\%)

\begin{tabular}{lcc}
\hline & \multicolumn{2}{c}{ unlabeled competitor } \\
\cline { 2 - 3 } & Ang & dAng \\
\hline 125I-Ang & $77 \pm 10$ & $18 \pm 10^{*}$ \\
125I-dAng & $6 \pm 2$ & $38 \pm 3$ \\
\hline
\end{tabular}

C

Internalization of Ang and dAng

\begin{tabular}{|c|c|c|c|c|}
\hline \multirow[b]{2}{*}{ Experimental conditions } & \multicolumn{2}{|c|}{$\begin{array}{l}\text { internalized } \\
\left(\mathrm{fmol} / 10^{6} \text { cells }\right)\end{array}$} & \multicolumn{2}{|c|}{ internalized/surface } \\
\hline & ${ }^{125}$ I-Ang & 125I-dAng & 125I-Ang & 125I-dAng \\
\hline serum & $0.83 \pm 0.15$ & $0.29 \pm 0.04$ & 0.09 & 0.03 \\
\hline serum-free & $1.38 \pm 0.13$ & $0.74 \pm 0.19$ & 0.09 & 0.03 \\
\hline
\end{tabular}


Figure 4

A

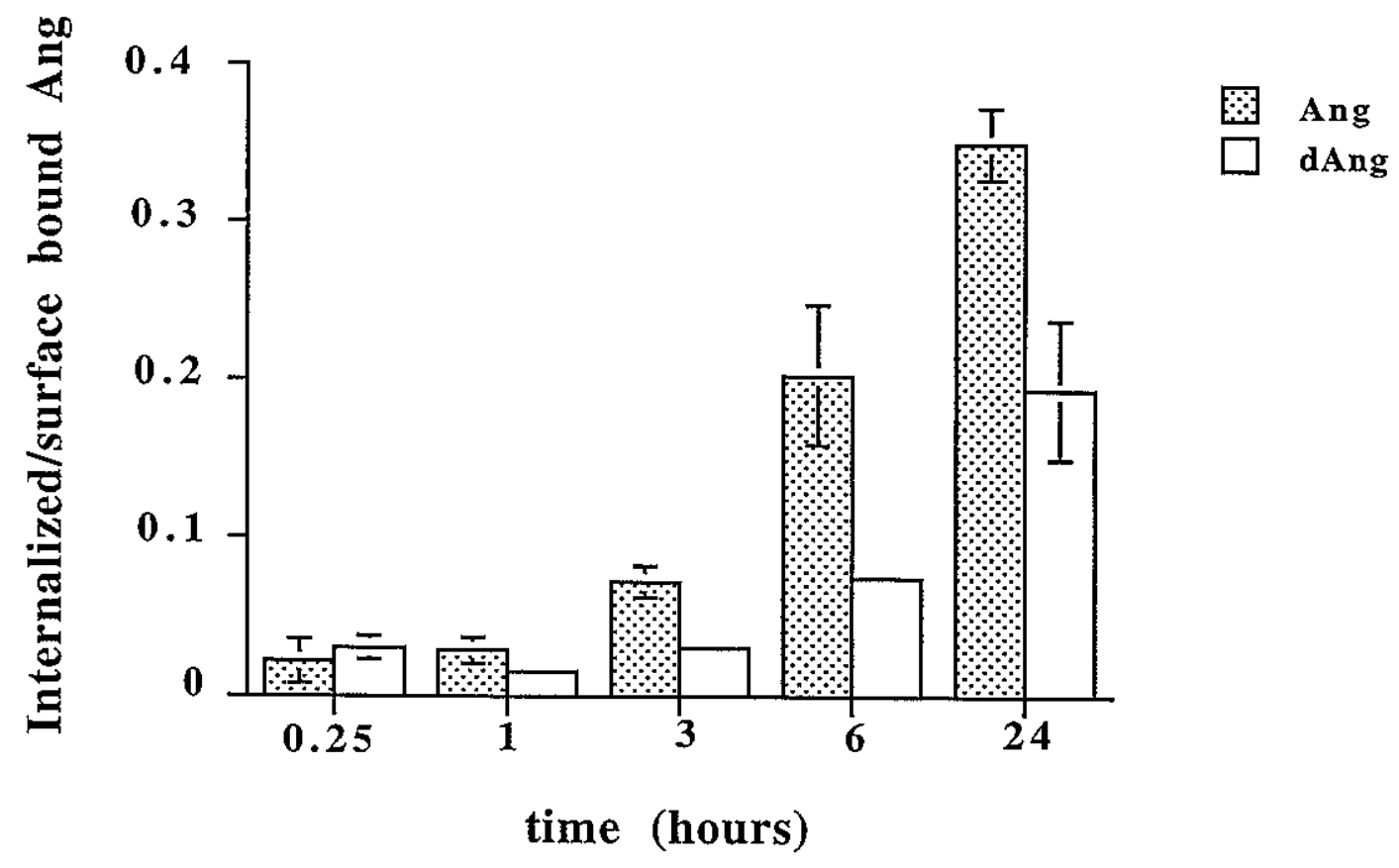

B

Cells

Time

(hours)
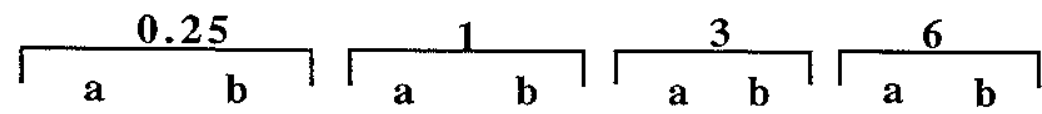

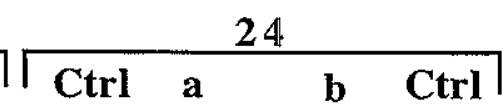

$\mathrm{Mr}(\mathrm{kDa})$

14.4

10.2
8.7 
Figure 5

A

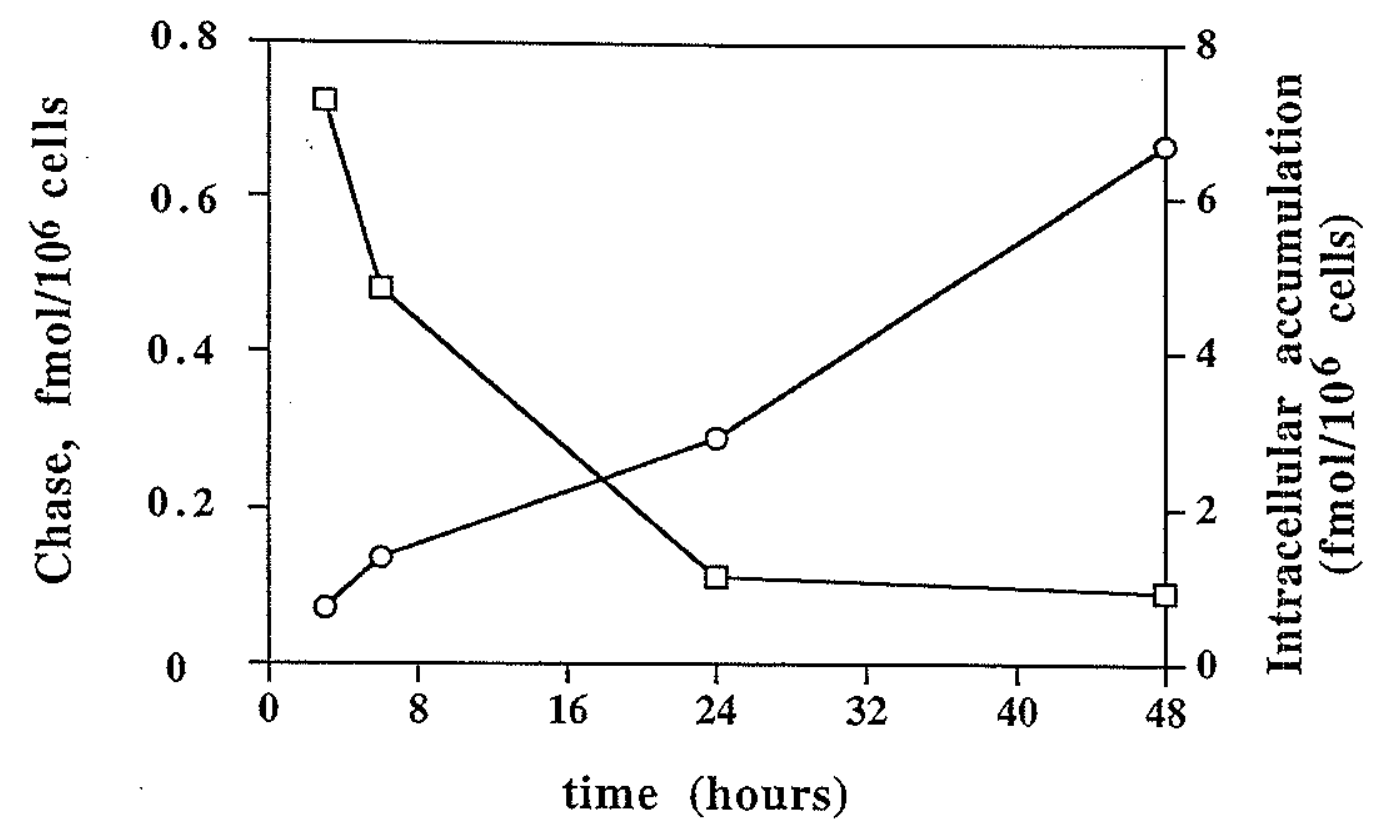

B

Ang Ctrl a b

Mr (kDa)

14.4

10.5

6.1 